\title{
Relationship between intrapulmonary and endo- bronchial cartilage-containing tumours (so-called hamartomata)
}

\author{
ERIC M . B ATESON ${ }^{1}$ \\ From the Departments of Radiology of the United Sheffield Hospitals
}

There are two types of benign tumours containing cartilage which occur within the thoracic cage. The common variety found in the lung parenchyma (intrapulmonary) surrounded by normal lung is usually asymptomatic and presents radiologically as a 'coin lesion'. The less common variety occurs as an endobronchial tumour and presents with clinical and radiological features of bronchial obstruction. The terminology of these cartilage-containing tumours is very confused. This is partly due to the many theories of their histogenesis, partly to the variation in their structure, and partly to their two ways of presentation (intrapulmonary and endobronchial).

They were originally, and often still are, called 'chondromata'. Names describing their component tissues have been applied to these tumours, varying from the relatively simple term 'adenochondroma' (Jackson, 1952) to the more complex term 'adeno-lipo-fibro-osteo-chondroma' (Peters, 1932). Since the introduction of the concept of the hamartoma by Albrecht in 1904, these cartilage-containing tumours have often been referred to as hamartoma, hamarto-chondroma, or chondromatous hamartoma on the assumption that they are developmental malformations. Recently, Willis (1958) referred to them as 'mixed tumours of the lung'.

The relation between these two types of cartilage-containing tumours is not well defined, and there is disagreement in the literature about this. Bianchi and Etchegoyen (1945), Liebow, (1952), McDonald, Harrington, and Clagett (1945), Roujeau (1961), Schaefer (1955), Santy, Bérard, Breton, and Galy (1951), and Simon (1948) regard the intrapulmonary and endobronchial types of these cartilage-containing tumours as separate lesions, and Franco (1958) said, 'There is a tendency towards a precise topographical and

1 Present address : Department of Radiology, The Royal Perth Hospital, Wellington Street, Perth, Western Australia histological separation of the two forms'. Bikfalvi, Molnár, and Horányi (1954), Cavin, Masters, and Moody (1958), Chardack and Waite (1953), Donoghue, Andersen, and McDonald (1956), Filippi (1953), Green (1959), Hall (1948), Muendel and Yelin (1955), Postlethwait, Hagerty, and Trent (1948), Santoro and Nerone (1958), Rubin and Berkman (1952), Sherrick (1952), Stein and Poppel (1955), Terracol, Fabre, and Guerrier (1948), Young, Jones, Hughes, Foley, and Fox (1954), and Zeitlhofer (1954) take the opposite view and regard both the intrapulmonary and the endobronchial cartilaginous tumours as the same lesion.

In view of this dichotomy of opinion, a study of 36 cartilage-containing tumours was carried out in an attempt to see if the two types were the same or different tumours.

Evidence from the literature and from the present series of 36 cases will be used to show that intrapulmonary and endobronchial cartilage-containing tumours are the same tumour, differing in appearance solely because of their different site of origin.

\section{EVIDENCE FROM THE LITERATURE}

DESCRIPTION OF TUMOUR Without going deeply into their histological structure at this stage, it is felt that a brief description of these cartilaginous tumours is necessary to identify the nature of the lesions under discussion.

These tumours are usually composed of a mixture of mesenchymal and epithelial tissues. Myxomatous connective tissue is always present, but usually cartilage is found in the greatest quantity. In addition, fat, smooth muscle, bone, red and fatty marrow, blood vessels, and round cells (lymphocytes, plasma cells, and polymorphs) may be present. Occasionally, myxomatous connective tissue or fat may predominate. The 
mesenchymal components are arranged in lobules separated by cleft-like and branching spaces lined by epithelium of a respiratory type (cubical, cylindrical, stratified, or ciliated) which may also form cystic spaces.

This description, with minor variations, can be applied to most of the intrapulmonary cartilagecontaining tumours, and it is also applicable to a few of the endobronchial cartilage-containing tumours. The latter are covered by bronchial mucosa continuous with that lining the bronchus from which they arise. The covering mucosa may be invaginated in places into the depths of the tumour to form clefts which may appear as cystic spaces when cut transversely. There is usually no connexion between the cartilage of the tumour and that of a bronchial ring. Most of the endobronchial cartilage-containing tumours do not contain the epithelial-cell-lined clefts which are such a constant feature of the intrapulmonary form, but they are formed from the same tissues in a similar, though not identical, arrangement. This difference makes the two tumours (endobronchial and intrapulmonary) appear, at least superficially, to be different tumours.

Adequate descriptions of intrapulmonary cartilage-containing tumours have been given by Filippi (1953), Carlsen and Kiaer (1950), Goldsworthy (1934), Hall (1948), Jaeger (1935), Liebow (1952), Novi (1955), and Roujeau (1961), and of endobronchial cartilage-containing tumours by Bikfalvi et al. (1954), Davidson (1941), DoyleKelly (1960), Huet (1949), Meyer, Delarue, Monod, and Raugel (1942), Rose and Lansade (1958), Spiess (1910), and Sutherland, Aylwin, and Brewin (1953).

AGE AND SEX INCIDENCE If both intrapulmonary and endobronchial cartilage-containing tumours are the same neoplasm, then one would expect the age and sex incidence of the two types of tumour to be similar. In order to obtain a sufficient number of cases, 159 papers $^{1}$ containing the reports of 457 cartilage-containing tumours were reviewed. Of these 457 tumours, $368(80.5 \%)$ were intrapulmonary and $89(19.5 \%)$ were endobronchial.

Intrapulmonary tumours Endobronchial tumours (The sex was not given in 72 reports of intrapulmonary and 11 reports of endobronchial tumours.)

\footnotetext{
1 The inclusion of all these references would have made the bibliography too extensive, but they will be supplied by the author on request. They are also available in the author's thesis (see Bateson, 1963).
}

Although the male preponderance is more 들 marked with endobronchial cartilage-containing tumours, the sex ratios are similar.

Most of the endobronchial cartilage-containing $\%$ tumours reported in the literature presented $\overrightarrow{0}$ clinically with symptoms due to the position of the tumour in a bronchus. Most of the intrapulmonary $\vec{\omega}$ cartilage-containing tumours were incidental findings, discovered either on routine chest radio- $\vec{x}$ graphy or during necropsy. Those presenting $\mathbb{O}^{\circ}$ radiologically can, however, be regarded as ir presenting clinically, and it is only those intra- + pulmonary tumours presenting radiologically and $\overrightarrow{ }$ removed surgically which are compared with the $\frac{\text { ? }}{5}$ endobronchial tumours in Figure 1. This com- $\vec{c}$

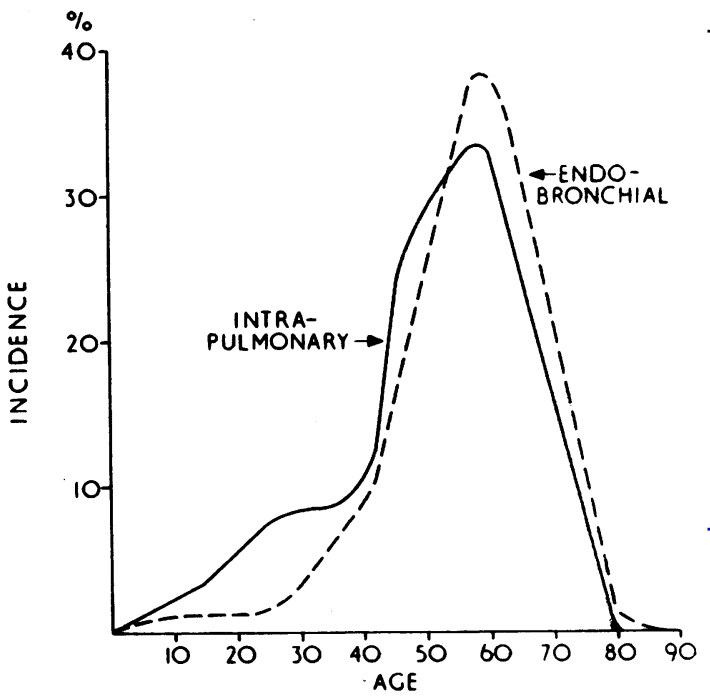

G. 1. Shows the age incidence of the intrapulmonary and endobronchial cartilage-containing tumours which have been reported in the literature.

parison is legitimate, because, although the endobronchial tumours have to attain a certain size $\frac{D}{0}$ before they produce symptoms (by interference with the bronchial lumen), the intrapulmonary o tumours also have to attain a certain size before $N$ their shadows are visible radiologically.

Of the 368 case reports of intrapulmonary cartilage-containing tumours reported in the literature, the age was not given in 94 cases, and $\stackrel{O}{5}$ 95 of the tumours presented at necropsy. The age $₫$ was not given in 11 case reports of endobronchial tumours.

It can be seen from Figure 1 that there is a close correspondence between the ages of presentation of the endobronchial and intrapulmonary forms of cartilage-containing tumours. 
SIMILARITY OF TISSUES OF INTRAPULMONARY AND ENDOBRONCHIAL CARTILAGE-CONTAINING TUMOURS A tissue analysis was carried out of the 457 mixed tumours reported in the literature. The histological descriptions were inadequate in 126 of the 368 intrapulmonary tumours and in 26 of the 89 endobronchial tumours.

The results of the analysis are given in Table $I$.

T A B LE I

\begin{tabular}{|c|c|c|c|c|c|}
\hline \multirow{2}{*}{\multicolumn{4}{|c|}{ Tissue }} & \multicolumn{2}{|c|}{ Cartilage-containing Tumours } \\
\hline & & & & \multirow{2}{*}{\begin{tabular}{|c|} 
Intrapulmonary \\
226 \\
221 \\
91 \\
25 \\
6 \\
40 \\
42 \\
208
\end{tabular}} & \multirow{2}{*}{\begin{tabular}{|c|} 
Endobronchial \\
63 \\
45 \\
34 \\
16 \\
8 \\
12 \\
9 \\
71
\end{tabular}} \\
\hline $\begin{array}{l}\text { Cartilage } \\
\text { Loose connective } \\
\text { Fat .. . . } \\
\text { Bone . } \\
\text { Bone marrow } \\
\text { Smooth muscle } \\
\text { Lymphoid cells } \\
\text { Epithelial-cell-lin }\end{array}$ & 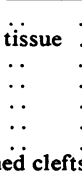 & $\begin{array}{l}\cdots \\
\cdots \\
\cdots \\
\cdots \\
\cdots \\
\text { ts }\end{array}$ & $\begin{array}{l}\cdots \\
\cdots \\
\cdots \\
\cdots \\
\cdots \\
\cdots\end{array}$ & & \\
\hline
\end{tabular}

1 Does not include clefts extending from surface of tumour

There is a marked similarity between the frequency of occurrence of the various tissues in the two types of tumour, with the exception of that of epithelial-cell-lined clefts.

\section{ATYPICAL FEATURES}

Absence of cartilage Examples of intrapulmonary tumours consisting of fibrous and myxomatous connective tissue and epithelial tissues without any cartilage but showing a similar structure to cartilage-containing tumours have been reported by Hodges (1958), Jensen and Schiødt (1958), Kirschner and Kny (1957), Leménager, Rousselot, and Bézard (1959), Lemon and Good (1950), McDonald et al. (1945), Porras, Lalane, and Degrossi (1958), Rousselot, Leménager, and Bézard (1959), and Scarff and Gowar (1944). A few intrapulmonary cartilage-containing tumours consisting predominantly of fatty tissue and epithelial clefts, with only a few small areas of cartilage, have been reported by Brewer, Brookes, and Valteris (1953), Feller (1922), Möller (1933), and Touroff and Seley ${ }^{1}$ (1951). Engelking (1959), Paterson (1956), and Perry (1959) have reported endobronchial tumours composed mainly of fatty tissue. These were referred to by the authors as 'hamartomata' and are therefore classifiable with the cartilagecontaining tumours. Hummel, Roussel, and Triboulet (1960), Moore (1932), Sherrick (1952), and Store (1954) have reported endobronchial

\footnotetext{
1 This tumour was reported as a lipoma.
}

'hamartomata' composed mainly of fat but also containing a few areas of cartilage, and Honig (1934) and Som and Feuerstein (1951) have reported endobronchial 'lipomata' containing small areas of cartilage or bone.

Presence or absence of epithelial-cell-lined clefts and spaces The majority of intrapulmonary cartilage-containing tumours contain clefts and spaces lined by epithelial cells of respiratory type. A few intrapulmonary cartilage-containing tumours which did not contain these epithelial structures have been reported by Bikfalvi et al. (1954), Edling (1938), Franco (1958), Hochberg and Pernikoff (1950), Klages (1931), Lemon and Good (1950), McDonald et al. (1945), Novi (1955), Roujeau (1961), and Santy et al. (1951).

Endobronchial cartilage-containing tumours do not usually contain epithelial-cell-lined clefts and spaces of the type seen in intrapulmonary cartilage-containing tumours. A few endobronchial cartilage-containing tumours which showed deep epithelial-cell-lined clefts extending from the mucosa covering the surface of the tumour have been reported by Hasche and Haenselt (1960), Itoiz, Latienda, and Murray (1947), Pacheco, Rivero, Tamayo, Green, and Rohde (1955), Rose and Lansade (1958), Roujeau (1961), Schields and Lynn (1958), and Sutherland et al. (1953). Examples of endobronchial cartilage-containing tumours with epithelial-cell-lined clefts of the type seen in intrapulmonary cartilage-containing tumours have been reported by Green (1959), Reboud, Bonneau, de Cutolli, and Ottavioli (1952), and Santy, Galy, and Touraine (1953).

Attachment of cartilage-containing tumours to bronchi Most intrapulmonary cartilage-containing tumours do not show any obvious connexion with a bronchus. However, cases of intrapulmonary cartilage-containing tumours attached to the external wall of a small bronchus have been reported by Franco (1958), Negre, Martin, and Loubatières (1954), Nigam (1957), Novi (1955), Rubin and Berkman (1952), Sherrick (1952), Stein and Poppel (1955), and Weisel, Glicklich and Landis (1955). A few intrapulmonary cartilagecontaining tumours with a small bronchus entering their substance have been reported by Favre (1935), Mammer (1927), and Möller (1933).

Corajod and Bérard (1952), while enucleating a cartilage-containing tumour, opened up a small bronchial lumen. A similar observation was made by Touroff and Seley (1951). They regarded their tumour as a lipoma, but it contained cartilage and could be classified with the cartilage- 
containing tumours. Endobronchial cartilagecontaining tumours are obviously connected to bronchi.

Summary of evidence from the literature The following features support the view that both intrapulmonary and endobronchial cartilagecontaining tumours are the same lesion: (a) The similarity of the sex incidence; $(b)$ the similarity of the age distribution ; $(c)$ the fact that both types of cartilage-containing tumours contain the same tissues with approximately similar frequency; (d) the fact that cartilage, the most characteristic constituent, may be absent from both forms; (e) the presence of intermediate forms, i.e., intrapulmonary cartilage-containing tumours without epithelial-cell-lined clefts, and endobronchial cartilage-containing tumours containing epithelialcell-lined clefts; and $(f)$ the obvious bronchial connexion of several intrapulmonary cartilagecontaining tumours.

\section{THE PRESENT STUDY}

The present series consisted of 36 cartilagecontaining tumours; 32 were intrapulmonary and four were endobronchial. Thirty-four of the tumours were resected, the other two were examined at necropsy. Twenty-seven of the tumours $(75 \%)$ occurred in male patients. The age incidence is given in Table II.

T A B L E I I

\begin{tabular}{cc|c|c|c|c|c|c}
\hline & & \multicolumn{6}{c}{ Age (years) } \\
\cline { 3 - 7 } & & $20-29$ & $30-39$ & $40-49$ & $50-59$ & $60-69$ & $70-79$ \\
\hline $\begin{array}{l}\text { No. of cases } \\
\%\end{array}$ & $\cdots$ & 2 & 4 & 7 & 5 & 5 & 1 \\
\hline
\end{tabular}

Most of the intrapulmonary cartilage-containing tumours were in a peripheral position in the lobe and were nearly all very loosely attached to the surrounding lung, often being 'shelled out' without difficulty during thoracotomy. Three of the intrapulmonary tumours were connected to the lung by a pedicle, and in one of these the pedicle contained a sheath of blood vessels. All the tumours examined by the author had a shiny surface (Fig. 2) as if covered by a thin mucous membrane. Microscopic sections of 33 of the 36 tumours were available. Complete details of the macroscopic and microscopic appearances are not given, since in most cases these were typical of cartilage-containing tumours of the lung (Figs 3 and 4).
PATHOLOGY Six features were noted which have not been commented on in reports in the litera $\overline{\bar{n}}$ ture, or, if mentioned, very little significance has been placed on them: they will be discussed later 0

1. In all the tumours (intrapulmonary and endos bronchial) there was always a gradual transition $\overrightarrow{0}$ between the periphery of the lobules of cartilageand the surrounding connective tissue, often withw almost imperceptible changes between the fibro cytes and chondrocytes (Figs 5, 6, and 7).

2. The distribution of the epithelial clefts withino the tumours was studied, and the results are givenor in Table III. The epithelial-cell-lined clefts weret+

T A B LE III

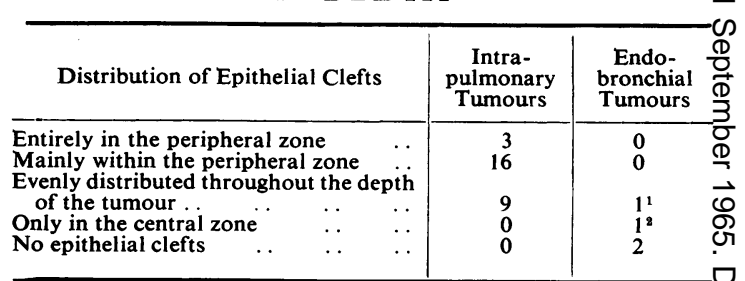

This endobronchial tumour arose from the wall of a small basap bronchus of the left lower lobe.

${ }^{2}$ In this endobronchial tumour the mucous membrane on the surface of the tumour formed deep invaginations into the deeper partso of the tumour, which became continuous with the epithelial-cell-lined clefts within the central part of the tumour.

found mainly in the peripheral zones of the intra- $\overrightarrow{\bar{O}}$ pulmonary cartilage-containing tumours (Fig. 3). .3

3. The epithelial clefts formed double-layered sheets with an intervening space covering the external surface of the lobules of cartilage forming the edge of the intrapulmonary tumour. These double-layered sheets (encircling clefts) thereforex separated the compressed alveoli of the lung surrounding the tumour from the connective tissue around the outer edges of the peripheralo lobules of the intrapulmonary tumours (Figs 3 and 8). These encircling clefts did not form a continuous double layer completely covering the $>$ tumour but overlapped and were interrupted at many points. They were also continuous withN other epithelial-cell-lined clefts which passed in between the lobules of the outer zone of the tumours. The ease with which intrapulmonary $\omega$ tumours can be enucleated is probably due to separation taking place through these encirclinge clefts. These encircling clefts were present around $\mathbb{\Phi}$ 27 of the intrapulmonary tumours and are shown? diagrammatically in Fig. 13, no. 1.

4. In some areas of most intrapulmonary cartilage-containing tumours there were projec- $\stackrel{\square}{\mathbb{\perp}}$ tions of the connective tissues invaginating the $\propto$ epithelium lining the clefts and also distorting 
FIG. 2. Macroscopic appearance of a typical intrapulmonary cartilage-containing tumour after enucleation from the lung. Note the lobulated appearance of the external surface (left) and the cross-section (right). The externald surface was shiny.
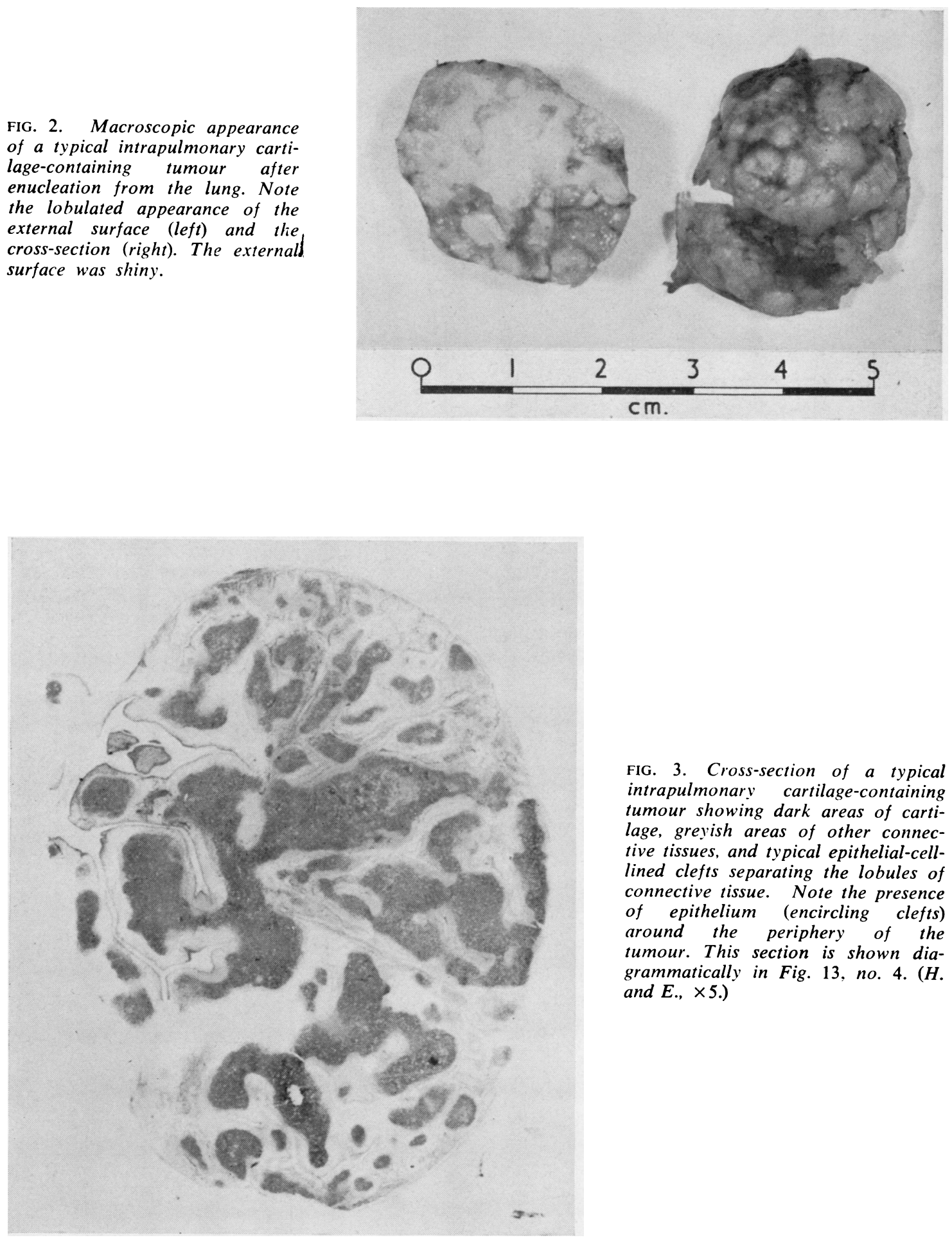

FIG. 3. Cross-section of a typical intrapulmonary cartilage-containing tumour showing dark areas of cartilage, grevish areas of other connective tissues, and typical epithelial-celllined clefts separating the lobules of connective tissue. Note the presence of epithelium (encircling clefts) around the periphery of the tumour. This section is shown diagrammatically in Fig. 13, no. 4. (H. and $E$., $\times 5$.) 


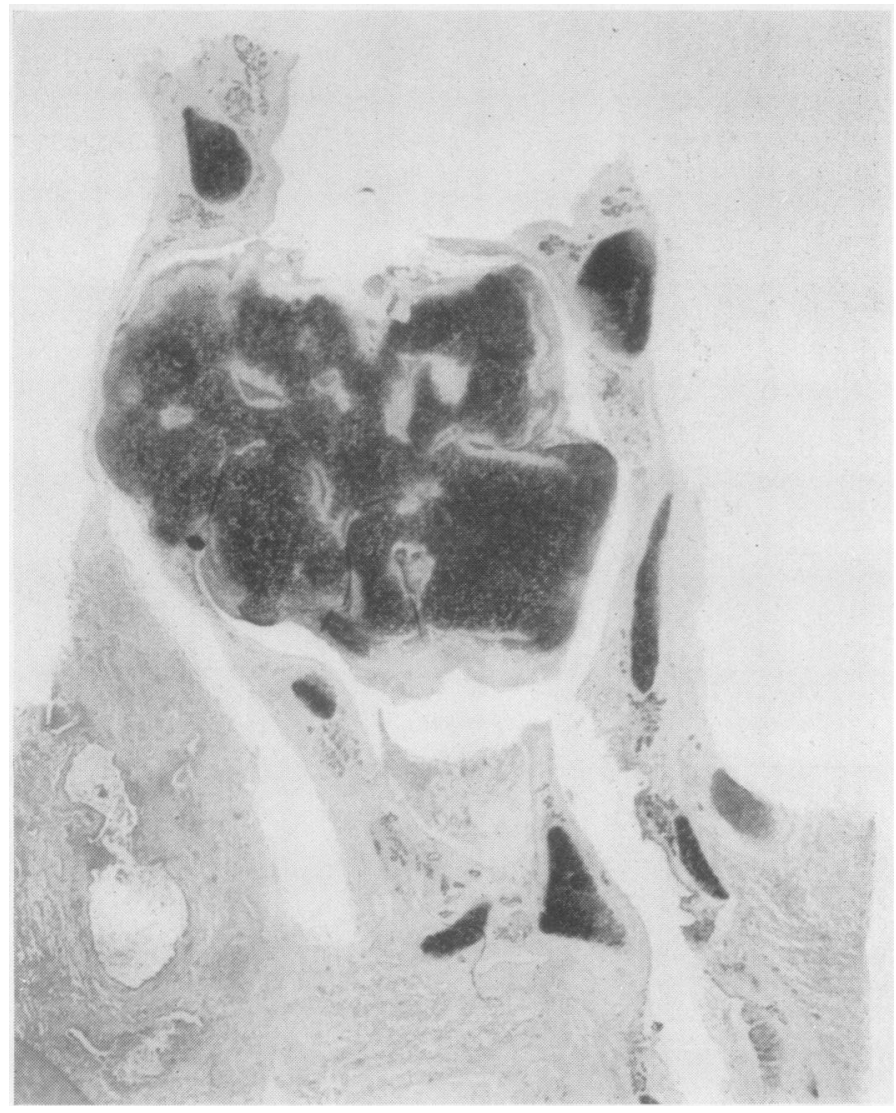

FIG. 4. Cross-section of a typical endobronchial cartilage-containing tumour which consists of a single $\unrhd$ mass of cartilage with an external covering of connective tissue and respiratory epithelium. Note the absence of any infolding of the epithelium. Cartilage of the bronchial rings is also shown. This section is shown diagrammatically in Fig. 12, no. 2. (H. and E., $\times 6$.)

FIG. 4 from the edge of an intrapulmonary cartilage-containing tumour, showing loose connective tissue in a lobular arrangement, the lobules being separated by clefts lined by epithelium. Various stages in the formation of areas of cartilage are shown, and many small projections of the connective tissue deforming the outline of adjoining epithelial-cell-lined clefts can be seen. (H. and E., $\times 70$.)

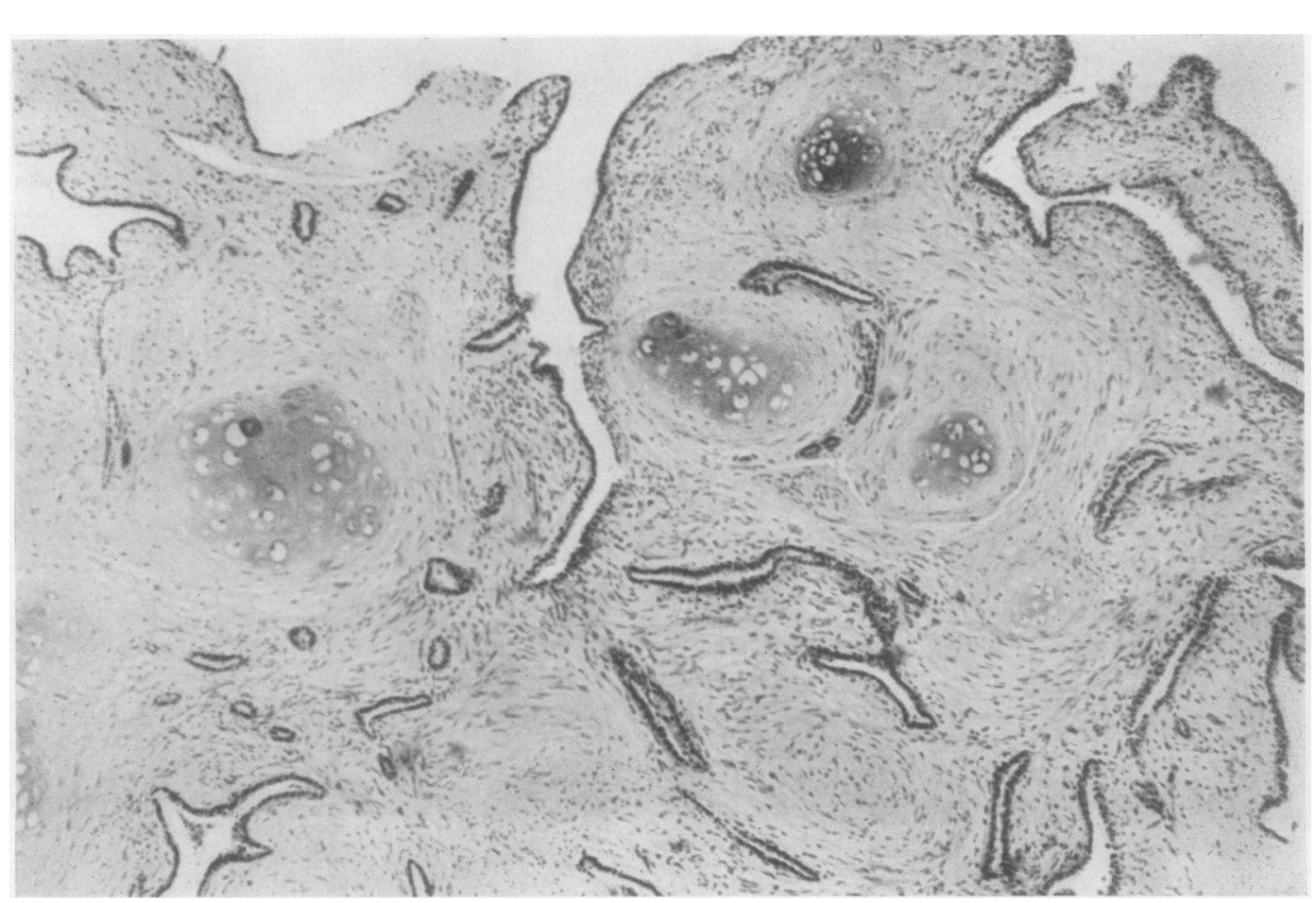

FIG. 5 


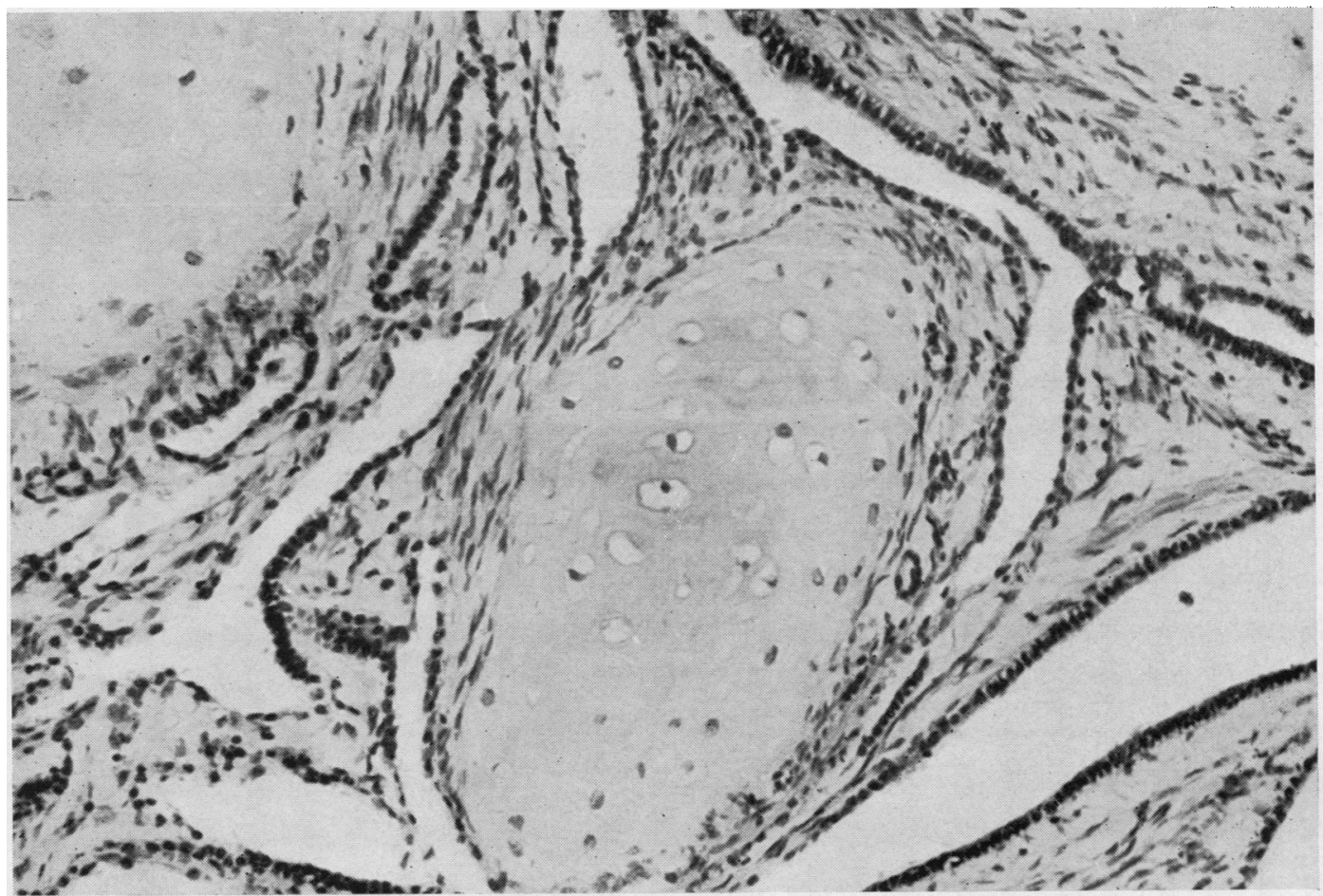

FIG. 6. Photomicrograph of an area from the edge of an intrapulmonary cartilage-containing tumour, showing the development of an area of cartilage in the loose connective tissue. $(H$. and E., $\times 130$.)

their shape. These projections, often papillary in appearance, were nearly always present in the peripheral zones of the tumours and rarely in their deeper parts. In many areas these projections, if cut transversely, appeared as islands of connective tissue covered by epithelium (Figs 5 and 6). The connective tissue forming these projections was usually myxomatous or loose in appearance, and often, in the centre, a small mass of immature cartilage was present (Figs 5 and 6). The appearance strongly suggested that cartilage was arising by transition of the connective tissue forming these projections, and that the peripheral zone was the site of growth of the intrapulmonary cartilage-containing tumours. These projections were present in one of the endobronchial cartilagecontaining tumours which had its origin in a small bronchus (Figs 9 and 10), the appearance of this tumour being identical with that of the intrapulmonary cartilage-containing tumours. In another endobronchial cartilage-containing tumour these projections were also present to a lesser extent (Fig. 7).

5. Mucous glands were present in five of the intrapulmonary cartilage-containing tumours.
These glands were in the connective tissue usually close to an epithelial cleft (Fig. 11). Mucous glands were present in the base of two of the endobronchial tumours.

6. The peripheral zones of both the intrapulmonary and endobronchial tumours were the most vascular parts and were also the site of smooth muscle fibres when present.

COMPARISON OF INTRAPULMONARY AND ENDOBRONCHIAL CARTILAGE-CONTAINING TUMOURS

Drawings were made of a cross-section of each of the four endobronchial tumours (Fig. 12) and four of the intrapulmonary tumours (Fig. 13). These drawings were made to show the arrangement of the cartilage, the loose connective tissue, and the epithelium.

The drawings of the four endobronchial cartilage-containing tumours are arranged in order of increasing complexity of structure. Numbers 1 and 2 (Fig. 12) show a very simple structure, being formed of a single mass of cartilage (not connected to a bronchial ring), a layer of connective tissue, and a covering of bronchial epithelium which is continuous with that lining the bronchus. 


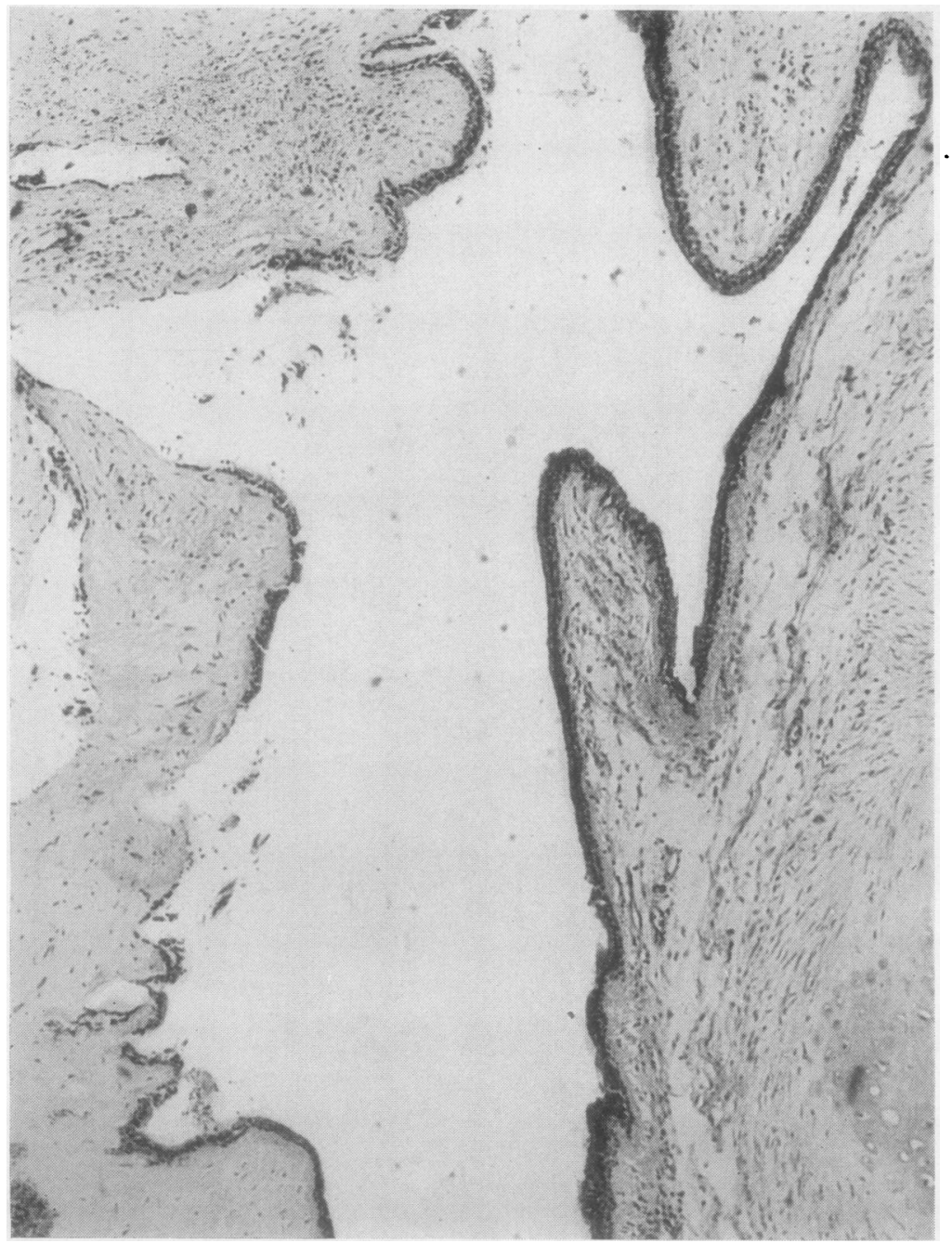

FIG. 7. Photomicrograph $\stackrel{\times}{\mathrm{O}}$ of an area from the of deeper part of the endobronchial cartilage-con- $\underset{\forall}{ }$ taining tumour shown 0 diagrammatically in Fig. 12 , no. 3. The section shows a cleft lined by $\mathbb{D}$ columnar epithelium: the outline of the cleft is distorted by projections of the underlying connective tissue. Note how the cartilage and sur- of rounding loose connective tissue merge imperceptibly into each other. The appearance is very similar to that seen in intrapulmonary tumours. $(H$. and $E$., $\times 70$.)

Number 3 (Fig. 12) shows a more complex structure with deep invaginations of the surface epithelium. The cavities of the invaginations appear in places as isolated spaces surrounded by epithelium. Number 4 (Fig. 12) was an endobronchial tumour which arose from the wall of a small bronchus. The section shows many small epithelial clefts of the type seen in intrapulmonary mixed tumours. The appearance of this tumour is identical with that of a typical intrapulmonary cartilage-containing tumour.

The four intrapulmonary cartilage-containing tumours (Fig. 13) are all typical in appearance but were selected to show different degrees of complexity of structure, increasing in complexity from
1 to 4 . Few epithelial clefts are present in tumouro 1 , and these clefts are nearly all around the peri phery of the tumour. In 2,3 , and 4 there is ano increasing frequency of epithelial-cell-lined clefts $N$ these penetrate deeply into tumours 3 and 4 .

A comparison of the two sets of cartilage containing tumours shows many similarities between the two forms. Number 1 of the intrapulmonary tumours closely resembles nos. 1 and 2 of the endobronchial tumours. Number 2 of the intrapulmonary tumours closely resembles noo 3 of the endobronchial tumours, and no. 3 of the intrapulmonary tumours closely resembles no. 40 of the endobronchial tumours. This similarity in appearance of the two sets of tumours is inter- 


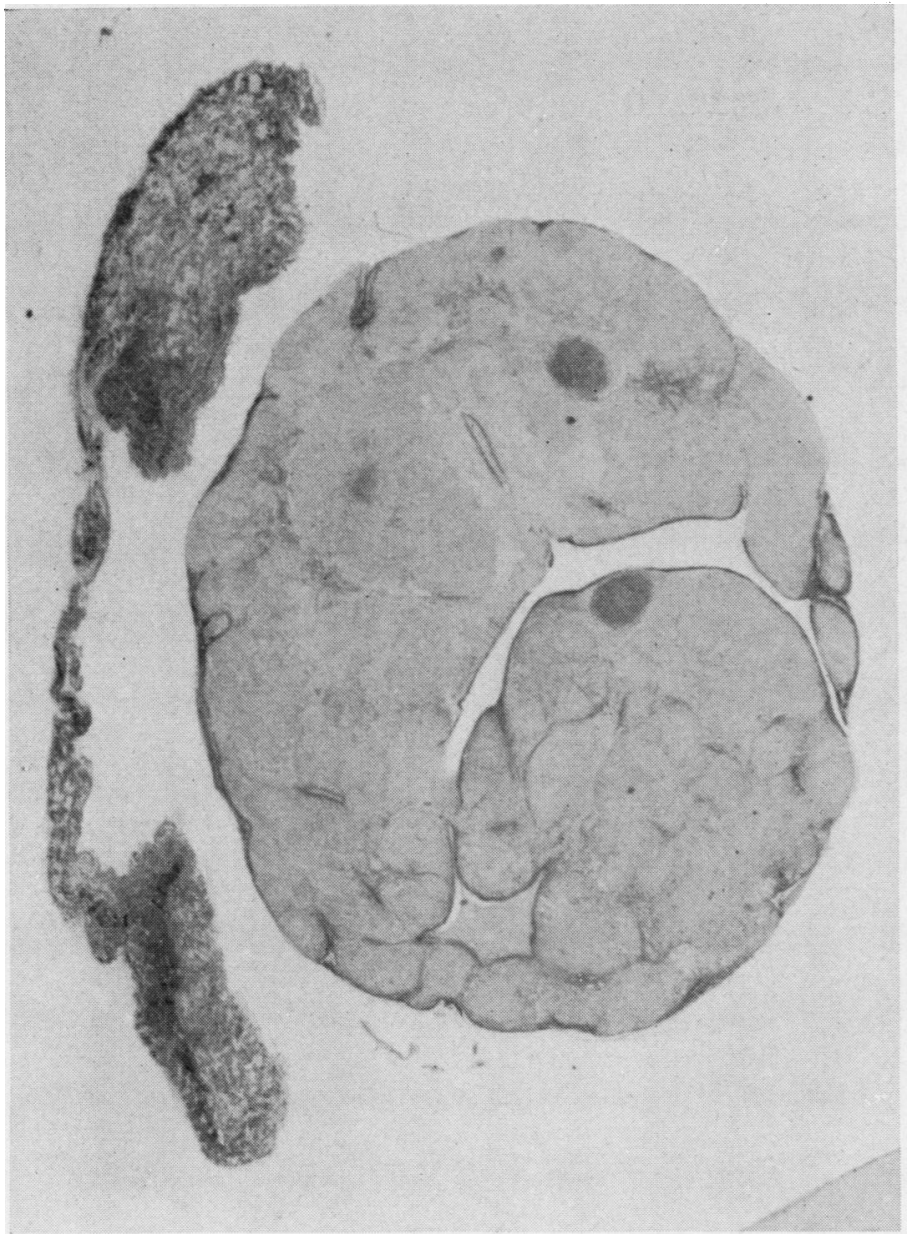

FIG. 8. Cross-section of an atypical intrapulmonary cartilage-containing tumour. This tumour was composed mainly of loose connective tissue, myxomatous in appearance with only three small areas of cartilage (the dark areas in the photograph). One large epithelial cleft and several smaller ones have been demonstrated. A single layer of epithelial cells, cubical or columnar, almost completely surrounded the tumour. (H. and $E$., $\times 5$.

FIG. 9. Cross-section of the endobronchial cartilage-containing tumour which arose in a small bronchus showing many epithelial-cell-lined clefts identical in appearance with the clefts seen in intrapulmonary tumours. This section is shown diagrammatically in Fig. 12, no. 4. (Masson, $\times 5$.)

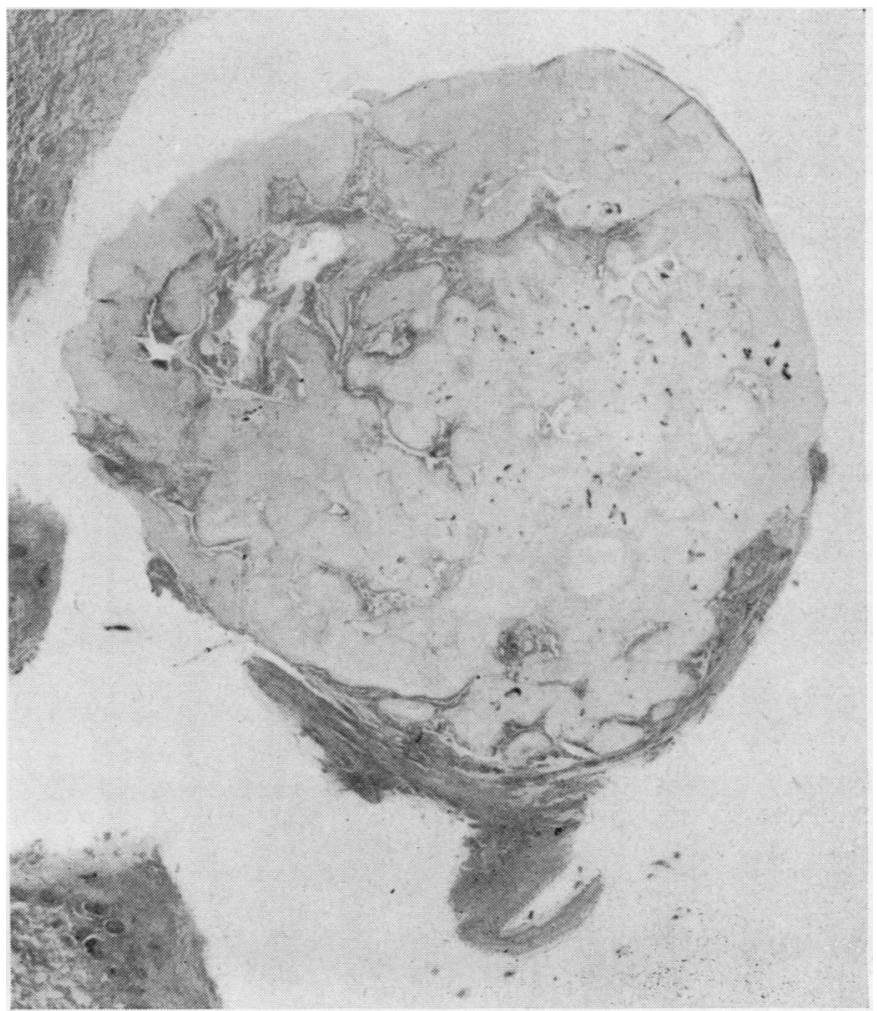




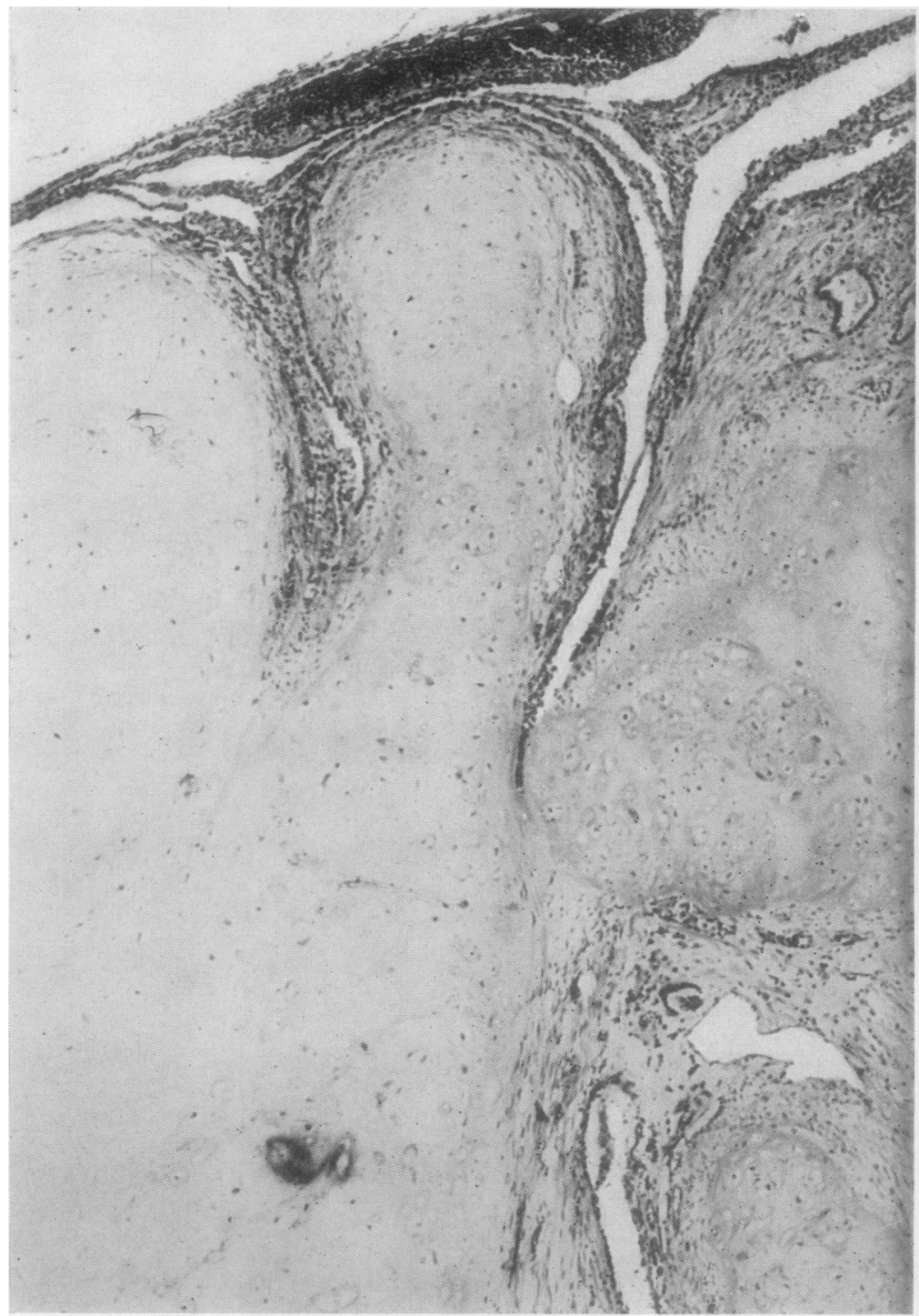

FIG. 10. Photomicrograph of an area from the edge of the endobronchial cartilage-containing tumour shown in Fig. 9. Two epithelial-cell-lined clefts extend from the surface of the tumour, separating lobules of cartilage. Much of the covering epithelium is denuded and there is marked infiltration by round cells. (Masson, $\times 70$.)

preted as evidence that intrapulmonary and endobronchial cartilage-containing tumours are the same lesion.

\section{DISCUSSION}

From a review of the literature there is much evidence to support the theory that both intra- pulmonary and endobronchial cartilage-containing tumours are the same or very similar tumours Sutherland et al. (1953) considered the relation of endobronchial cartilage-containing tumours to the intrapulmonary 'hamartoma chondromatosum pulmonis' (intrapulmonary cartilage-containing tumour). They said that in most instances the 


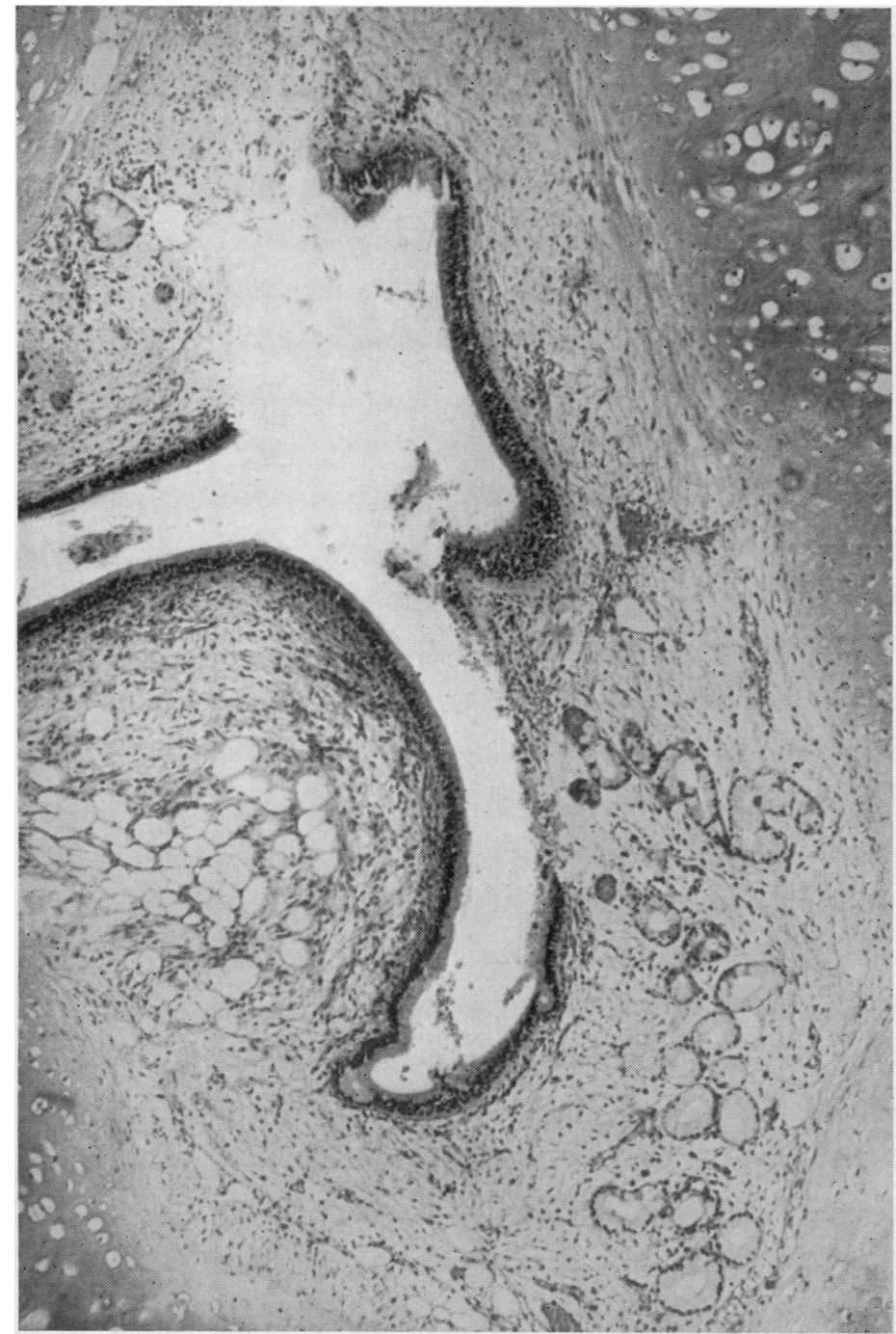

FIG. 11. Photomicrograph of an area from the deeper part of a typical intrapulmonary cartilagecontaining tumour. An epithelialcell-lined space is shown. The space was lined by ciliated epithelium of respiratory type with many mucous glands in the underlying connective tissue. The whole structure closely resembles a bronchiole. (H. and E., $\times 70$.)

various tissues accompanying the two forms of the tumour are identical. The pattern of the intrapulmonary tumour may be explained as a result of its origin in the wall of a small bronchus. The two forms of the tumour may differ only in their position in the bronchial tree, one originating in the wall of a large bronchus near the hilum (endobronchial), and the other in the wall of a small bronchus in the periphery (intrapulmonary). This view is confirmed by recorded cases which appeared to be intermediate in form, and Sutherland $e t$ al. quote the cases of Feller (1922), Hammer (1927), and Möller (1933), to which should be added those of Zeitlhofer (1954) and Hasche (1956), and probably that of Naib and Attar (1962).
The explanation of Sutherland et al. seems a reasonable way in which to relate the two forms of tumour. The fact that it was possible in the present series of cases to arrange four intrapulmonary and four endobronchial cartilagecontaining tumours in order of increasing complexity with overlap of the features of the two forms helps to confirm this explanation. Further support is given by the interpretation of the six special features of the cartilage-containing tumours in the present series.

1. The gradual transition between the periphery of the lobules of cartilage and the surrounding connective tissue is interpreted as evidence that the cartilage arises by metaplasia of connective tissue (presumably of the bronchial wall) in an 


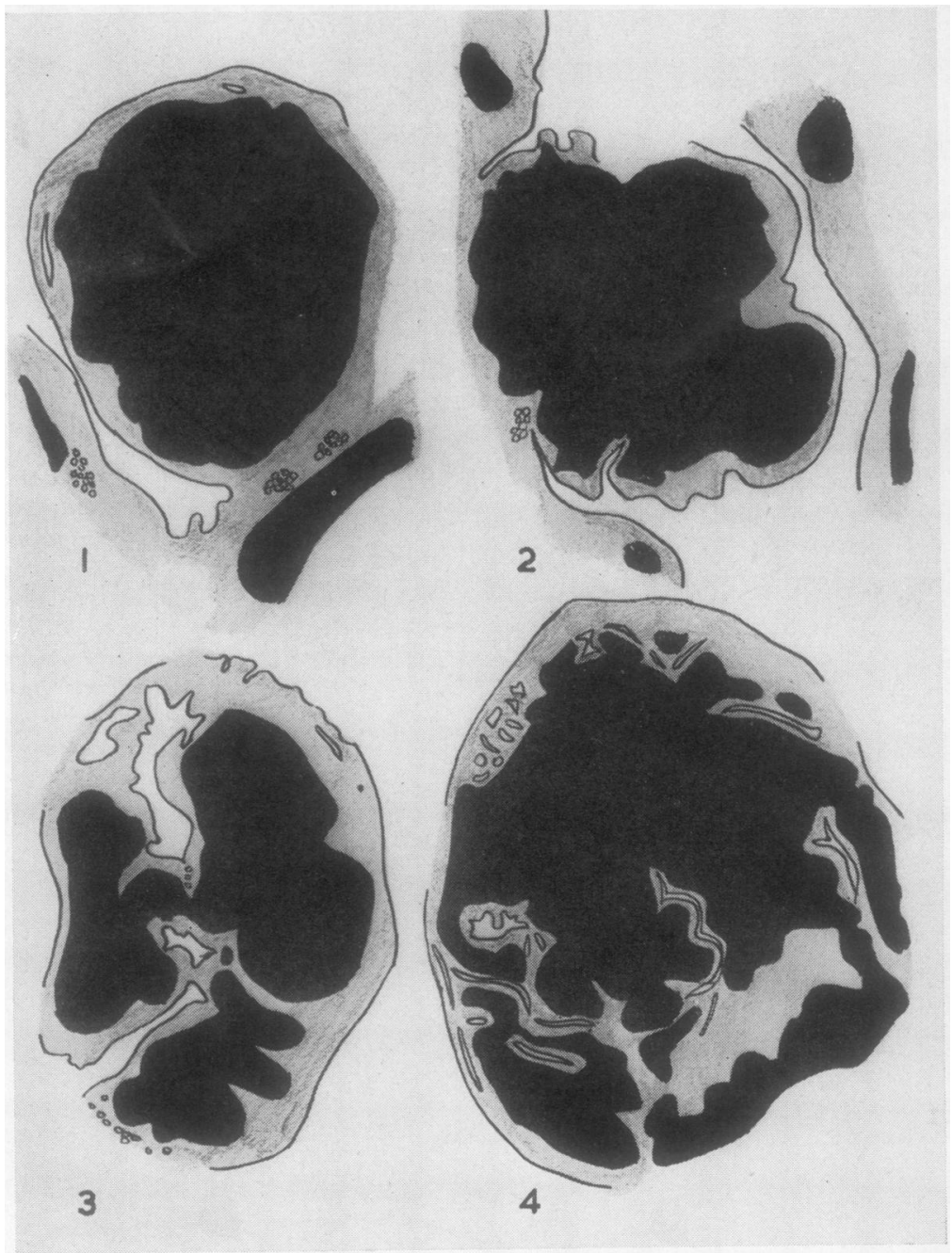

FIG. 12. Drawings of cross-sections of the four endobronchial cartilagecontaining tumours. The black areas are cartilage, the grey areas are connective tissues other than cartilage, and the epithelial layer around the connective tissue is shown as a black line. Mucous glands are shown as groups of small circles. Nos 1 and 2 show the relation of the tumour to the surrounding bronchial wall. The series shows increasing complexity from the simple structure of tumours 1 and 2, which consist of a single mass of cartilage, to the more complex form of tumours 3 and 4, which show deep clefts extending from the surface of the tumour and epithelialcell-lined clefts within the deeper parts of the tumours.

identical way in both intrapulmonary and endobronchial cartilage-containing tumours.

2 and 3. The concentration of epithelial tissue in the peripheral zone of the tumour, and the arrangement in the form of encircling clefts, can be interpreted as evidence that the intrapulmonary tumour has its origin in the connective tissue of the wall of a small bronchus, and the growth of the connective tissue of the tumour displaces the underlying epithelium around its periphery, the epithelium forming the encircling clefts. The other epithelial-cell-lined clefts in the peripheral zone were included during the growth of the connective tissue of the tumour. 


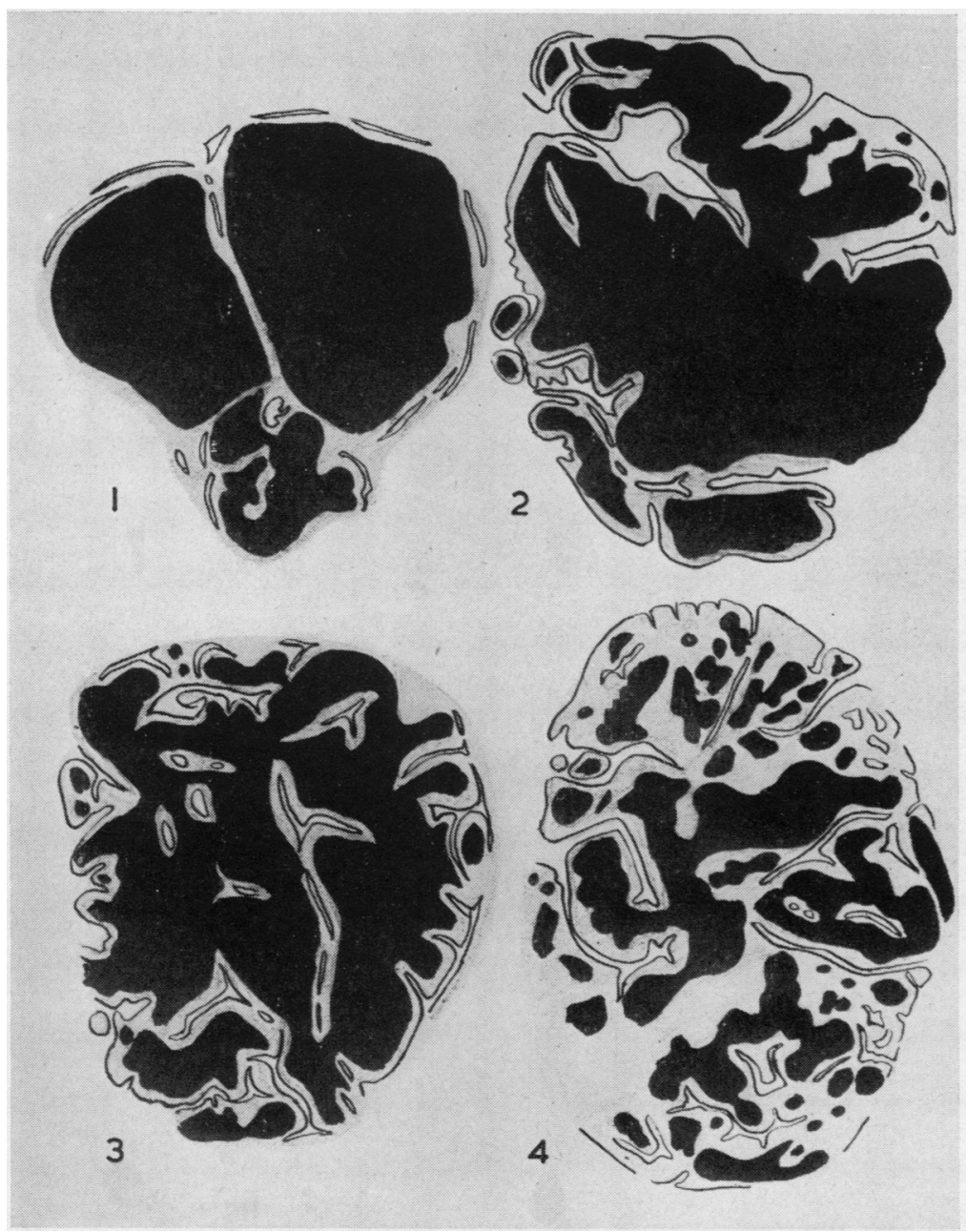

FIG. 13. Drawings of cross-sections of four of the intrapulmonary cartilage-containing tumours using the same scheme as in Fig. 12. Tumour 1 has a very simple structure with few clefts in its deeper part but many small epithelial-cell-lined clefts around its periphery (encircling clefts). The structure of the tumours becomes increasingly complex in nos 2, 3, and 4. In every case epithelial-cell-lined clefts limit the periphery of the tumours.

4. The projections of connective tissue, which are found mainly in the peripheral zones of intrapulmonary tumours, represent the continuing growth of the connective tissue and cartilage, with stretching of the overlying epithelium. Where this feature is prominent, the underlying projections of connective tissue are often very immature in appearance. A similar appearance is frequently seen in endobronchial tumours.

5. The presence of mucous glands in the subepithelial connective tissue of intrapulmonary tumours is further evidence of their endobronchial origin.

6. The fact that the peripheral zone of cartilagecontaining tumours is the most vascular part is confirmatory evidence that this is the site of most active growth. The presence of smooth muscle fibres in the peripheral zone of intrapulmonary tumours may be due to the displacement of these fibres from their original position in the submucous tissues of the wall of the bronchus of origin of the tumour. 

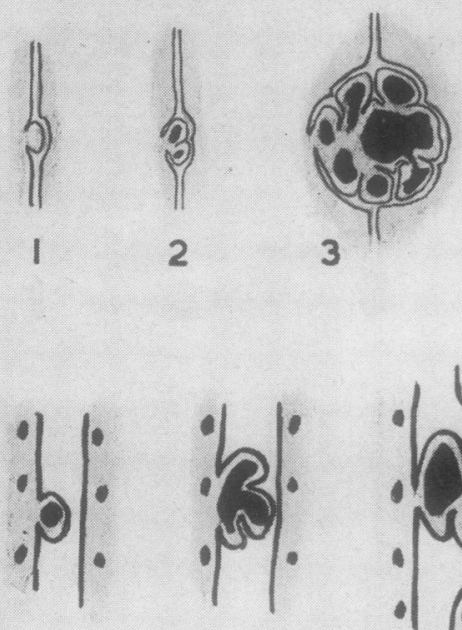

1

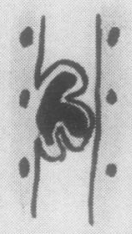

2

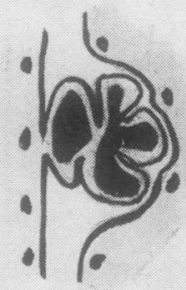

3
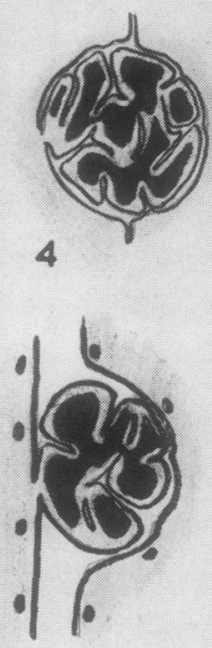

4
FIG. 14. Diagram illustrating the $\vec{\omega}$ development of cartilage-containing tumours. The upper series shows the development of an intra- i pulmonary tumour in the wall of a small bronchus, and the lower series the development of an endo- $\underset{\nabla}{\forall}$ bronchial tumour in the wall of a large bronchus. The diagram is partly based on Figs 12 and 13.
In the present series, three of the intrapulmonary cartilage-containing tumours were connected to the lung by a pedicle. This may represent the pedicle by which they arose from a small bronchus.

There is much evidence that intrapulmonary and endobronchial cartilage-containing tumours are the same tumour, differing in appearance only because of their different site of origin, and therefore I suggest that intrapulmonary cartilage-containing tumours should also be regarded as "endobronchial' tumours arising in the connective tissues of small bronchi. This is shown diagrammatically in Figure 14. If intrapulmonary cartilage-containing tumours arise in the submucous connective tissue of small bronchi, it could be argued that a connexion with a bronchus should always be shown. However, if the bronchus of origin is of microscopic size, it is quite possible that such a bronchus could be overlooked during enucleation of the tumour. Furthermore, a few cases have been reported in the literature in which a definite connexion between a typicai intrapulmonary cartilagecontaining tumour and a small bronchus was found.

\section{SUMMARY}

The pathological features of 32 intrapulmonary cartilage-containing tumours are described and compared with those of four endobronchial cartilage-containing tumours.
Intrapulmonary and endobronchial cartilagecontaining tumours have a similar age and sex incidence. Both types also show a similar range of morphological variation, differing only in their anatomical situation and in their mode of clinical $\overrightarrow{\overrightarrow{0}}$ and radiological presentation. Endobronchial 3 cartilage-containing tumours arise in the major bronchi, whereas there is a good deal of evidence? that intrapulmonary cartilage-containing tumours develop from peripheral bronchi.

This paper was based on part of a thesis accepted for the M.D. degree of the University of Sheffield.

The cases of cartilage-containing tumours were collected from the Chest Centre, Leicester ; the City Hospital, Nottingham; the City General Hospital, Sheffield; and the United Sheffield Hospitals ; and I 9 wish to acknowledge the permission of the surgeons $D$ and pathologists who allowed me to quote from their reports.

I wish to thank the Photographic Department of $\tilde{\sigma}$ the Radiotherapy Centre, Sheffield, who prepared the $N$ illustrations.

I am very grateful to the late Professor D. H. Collins, Department of Pathology, Sheffield University ; Dr. T. Lodge, Director of Radiology, the Royal Hospital, Sheffield; and Dr. G. Meachim, Lecturer in $\overparen{D}$ Pathology, Sheffield University, who have read the ? manuscript of both the thesis and this paper.

Mrs. I. Deans, of the University College Hospital of the West Indies, kindly typed the manuscript for me.

Finally, I wish to acknowledge the assistance given to me by my wife in the preparation of this paper. 


\section{REFERENCES}

Albrecht, E. (1904). Ueber Hamartome. Verh. dtsch. path. Ges., 7, 153. Bateson, E. M. (1963). M.D. Thesis, University of Sheffield. Bianchi, A. E., and Etchegoyen, H. (1945). Hamarciomas bronquicos intrapulmonares (dos casos). Rev. Asoc. méd. argent., 59, 787.

Bikfalvi, A., Molnár, J., and Horányi, J. (1954). Pathologie und Klinik der Hamarto-Chondrome der Lunge. Thoraxchirurgie, 2, 123 .

Brewer, D. B., Brookes, V. S., and Valteris, K. (1953). Adenochondroma of lung. Brit. J. Tuberc., 47, 156.

Carlsen, C. J., and Kiaer, W. (1950). Chondromatous hamartoma of the lung. Thorax, 5, 283.

Cavin, E., Masters, J. H., and Moody, J. (1958). Hamartoma of the lung. Report of one malignant and three benign cases. $J$. thorac. Surg., 35, 816

Chardack, W. M., and Waite, G. L.(1953). Chondromatous hamartoma of a main bronchus. Surgery, 34, 92 .

Corajod, M., and Bérard, J. (1952). Hamartochondrome évoluant depuis quinze ans. J. frarc. Méd. Chir. thor., 6, 427.

Davidson, M. (1941). A case of primary chondroma of the bronchus. Brit.J. Surg., 28, 571.

Donoghue, F. E., Andersen, H. A., and McDonald, J. R. (1956). Unusual bronchial tumors. Ann. Otol. (St. Louis), 65, 820.

Doyle-Kelly, W. (1960). Solitary chondroma of the right main bronchus. J. Laryng., 74, 780 .

Edling, N. P. G. (1938). Ein sogen. Lungenchondrom. Acta radiol. (Stockh.), 19, 44.

Engelking, C. F. (1959). Hamartoma of the trachea. Report of a case, with review of the literature of benign tracheal neoplasms. Laryngoscope (St. Louis), 69, 1278.

Favre, M. (1935). Thesis, Lyon. Quoted by Jaeger (1935).

Feller, A. (1922). Uber ein lipomähnliches Hamartom der Lunge. Virchows Arch. path. Anat., 236, 470.

Filippi, P. (1953). Contributo alla conoscenza istomorfologica ed istogenetica dei condromi broncopulmonari primitivi. Riv. Anat pat., 7,125 .

Franco, C. (1958). Considerazioni anatomo-patologiche e cliniche su alcuni casi di amartoma chondromatoso et di chondroma puro del polmone. Arch. ital. Chir., 83, 125.

Goldsworthy, N. E. (1934). Chondroma of the lung (Hamartoma chondromatosum pulmonis). J. Path. Bact., 39, 291.

Green, R. A. (1959). Endobronchial hamartoma. Amer. Rev. resp. Dis., 80, 65

Hall, W. C. (1948). The roentgenologic significance of hamartoma of the lung. Amer. J. Roentgenol., 60, 605.

Hammer, E. (1927). Les chondromes du poumon. Ann. Anat. path., 4 949.

Hasche, E. (1956). Zur Klinik der Hamarto-Chondrome der Lunge. Thoraxchirurgie, 3, 507.

and Haenselt, V. (1960). Die Hamartome der Lunge. Z. Tuberk., 116, 1 .

Hochberg, L. A., and Pernikoff, M. (1950). Primary chondromas of the lung. Dis. Chest, 17, 337.

Hodges, F. V. (1958). Hamartoma of the lung. Ibid., 33, 43.

Honig, A. (1934). Ein lipomartiges Grebilde des linken Stammbronchus. Mschr. Ohrenheilk., 68, 155.

Huet, P. C. (1949). A propos d'un chondrome bronchique. Ann. Oto-laryng. (Paris), 66, 93

Hummel, J., Roussel, A., and Triboulet, F. (1960). Lipomes endobronchiques. Sem. Hôp. Paris, 36, 516 .

Itoiz, O. A., Latienda, R. I., and Murray, A. J. (1947). Tres nuevas observaciones de hamarcioma bronquial (uno de ellos poliposo endobronquial). Rev. Asoc. méd. argent., 61, 614.

Jackson, A. V. (1952). Five cases of "adenochondroma" of the lung. Aust. N.Z.J. Surg., 21, 173.

Jaeger, L. (1935). A propos de quelques cas de "chondromes pulmonaires". Ann. Anat. path., 12, 811 .

Jensen, K. G., and Schiødt, T. (1958). Growth conditions of hamartoma of the lung. Thorax, 13, 233.

Kirschner, H., and Kny, W. (1957). Beitrag zur Kenntnis der Pathologie und Klinik der Hamartochondrome der Lunge. Thoraxchirurgie, 5,111 .

Klages, F. (1931). Uber die Chondrome der Lunge. Brunst Beitr. klin. Chir., 151, 661.

Leménager, J., Rousselot, J., and Bézard, J. (1959). Un cas d'hamartome du poumon. Sem. Hôp. Paris, 35, 2796.

Lemon, W. E., and Good, C. A. (1950). Hamartoma of the lung: the improbability of preoperative diagnosis. Radiologv, 55, 692.

Liebow, A. A. (1952). Atlas of Tumor Pathologv. Section V, Fascicle 17: "Tumors of the Lower Respiratory Tract". Armed Forces Institute of Pathology, Washington, D.C.

McDonald, J. R., Harrington, J. W., and Clagett. O. T. (1945). Hamartoma (often called chondroma) of the lung. $J$. thorac Surg., 14, 128.
Meyer, A., Delarue, J., Monod, O., and Raugel, M. (1952). Tumeur bénigne de la bronche gauche (harmartome?) traitée par bronchotomie après biopsie extemporanée. J. frar c. Méd. Chir. thor. 6,182 .

Möller, A. (1933). Zur Entstehung der Lungenmischgeschwülste. Virchows Arch. path. Anat., 291, 478.

Moore, R. A. (1932). Ueber ein polypöses Chondrom des Bronchus. Zbl. allg. Path. path. Anat., 55, 321 .

Muendel, H. J., and Yelin, G. (1955). Primary chondroma of the lung. Dis. Chest, 28, 103.

Naib, Z. M., and Attar, S. (1962). Exfoliative cytologic and clinical study of a case of endobronchial hamartoma of the lung. Ibid., 41, 468 .

Negre, E., Martin, G., and Loubatières, R. (1954). Les chondrohamartomes pulmonaires. Poumon, 10, 5.

Nigam, R. (1957). Indian J. Surg., 19, 259.

Novi, I. (1955). L'Amartoma condromatoso e il condroma puro del polmone. Arch. ital. Chir., 79, 315

Pacheco, C. R., Rivero, O., Tamayo, R. P., Green, L., and Rohde, F. C. (1955). Hamartoma endobronquial: comunicacion de un caso. Rev. mex. Tuberc., 16, 280

Paterson, J.F. (1956). Endobronchial hamartoma : a case report. Dis. Chest, 30, 559 .

Perry, D. C. (1959). Tracheo-bronchial and pulmonary chondroadenoma. Brit. med. J., 1, 1572.

Peters, R. (1932). Utber das sogenannte Lungenchondrom. Beitr. path. Anat., 89, 484.

Porras, T., Lalane, A., and Degrossi, F. (1958). Hamartoma carcinoma: dos tumores en el mismo lobulo pulmonar. Lobectomía. Pren. méd. argent., 45, 3531.

Postlethwait, R. W., Hagerty, R. F., and Trent, J. C. (1948). Endobronchial polypoid hamartochondroma: review of the literature and report of a case. Surgery, 24, 732 .

Reboud, Bonneau, de Cutolli, and Ottavioli (1952). Hamartome de la bronche lobaire supérieure gauche. Presse méd., 60, 1809.

Rose, Y., and Lansade, B. (1958). Hamartome bronchique. J. frarc. Méd. Chir. thor., 12, 322

Roujeau, J. (1961). Hamarto-chondromes broncho-pulmonaires. Rev. Tuberc. (Paris), 25, 991.

Rousselot, J., Leménager, J., and Bézard, J. (1959). Hamartome du poumon. Ann. Anat. path., 4, 461.

Rubin, M., and Berkman, J. (1952). Chondromatous hamartoma of the lung. $J$. thorac. Surg., 23, 393.

Santoro, M., and Nerone, G. (1958). Un caso di condroma puro del polmone. G. ital. Chir., 14, 549.

Santy, P., Bérard, M., Breton, A., and Galy, P. (1951). Tumeurs cartilagineuses intra-pulmonaires, hamarto-chondrome-ostéochondrome. J. fiar. . Méd. Chir. thor., 5, 248.

Galy, P., and Touraine, R. (1953). Les hamarto-chondromes bronchiques et pulmonaires. Ibid., 7, 329.

Scarff, R. W., and Gowar, F. J. S. (1944). Fibroadenoma of the lung. J. Path. Bact., 56, 257.

Schaefer, J. (1955). Zur Pathologie, Diagnostik und Therapie der chondromatösen Hamartome der Lunge. Thoraxchirurgie, 3, 60

Schields, T. W., and Lynn, T. E. (1958). Endobronchial hamartoma. Arch. Surg., 76, 358.

Sherrick, J. C. (1952). Endobronchial hamartoma. Quart. Bull. Northw. Univ. med. Sch., 26, 171.

Simon, M. A. (1948). Hamartomas of the lung and so-called "pulmonary adenomatosis". Amer. J. med. Sci., 216, 333.

Som, M. L., and Feuerstein, S. S. (1951). Endoscopic removal of lipoma of the bronchus. Arch. Otolaryng., 54, 341 .

Spiess, G. (1910). Ein Fall hochgradiger Dyspnoe, infolge eines Polypen im recten Bronchus. Münch. med. Wschr., 57, 2095.

Stein, J., and Poppel, M. H. (1955). Hamartoma of the lungs. Amer. J. Surg., 89, 439.

Store, S. D. (1954). A case of pulmonary hamartoma. Brit. med. J., 1, 25 .

Sutherland, T. W., Aylwin, J. A., and Brewin, E. G. (1953). Endobronchial chondromatous hamartoma. A report of two cases. J. Path. Bact., 65, 93.

Terracol, J., Fabre, L., and Guerrier, Y. (1948). Les tumeurs cartilagineuses bénignes. Ann. Oto-laryng. (Paris), 65, 42.

Touroff, A.S. W., and Seley, G.P. (1951). Lipoma of the bronchus and lung. Ann. Surg., 134, 244.

Weisel, W., Glicklich, M., and Landis, F. B. (1955). Pulmonary hamartoma, an enlarging neoplasm. Arch. Surg., 71, 128.

Willis, R. A. (1958). The Borderland of Embryology and Pathology. Butterworth, London.

Young, J. M., Jones, E., Hughes, F. A., Foley, F. E., and Fox, J. R. (1954). Endobronchial hamartoma. J. thorac. Surg., 27, 300.

Zeitlhofer, J. (1954). Zur Kenntnis der "Chondrome" (Hamartome) der Lunge. Beitr. path. Anat., 114, 271. 